\title{
The Effect of Audio-Podcast on Listening Comprehension of EFL Saudi Secondary Stage Students: Eastern Province
}

\author{
Mohammad Makki Al Sheef*
}

Dr. Naif Saad Althobaiti**

\begin{abstract}
:
The current study intends to investigate the effect of audio-podcasts, as a new learning and teaching tool, on the listening comprehension of Saudi EFL Secondary Stage students in the Eastern Province. It also examines the students' attitudes on using the audio-podcasts not only inside but also outside the classrooms. To meet the goals of the study, a three-week quantitative study, a quasi-experimental pre/post-test method, was applied. The study participants in both control and experimental groups were 30 Saudi secondary stage students at one of the Saudi public schools in the Eastern Province. The findings of the ANOVA technique showed that audio- podcasts' group performed better compared to the control group on the post-test. A 10item questionnaire was employed to collect and analyze the data by using the mean and standard deviation. The findings showed that students view the use of audio-podcasts as learning and training tool positively. The final result implies that using these modern applications as a supplementary material in the class is a very useful learning and teaching resource for enhancing the EFL students' listening comprehension.
\end{abstract}

Keywords: Audio-Podcasts, listening comprehension, Saudi students as EFL learners, attitude.

\section{Introduction}

\section{English as a Foreign Language: EFL}

Teaching and learning English become a necessity to many people around the world, because English has become the international language of education and business, not to mention science and technology. Most Saudi academic communities often use English in their settings. Despite the large number of English learners in the kingdom, EFL learning continues to follow an inclass-only learning model, with only little opportunities for the students to use English language beyond the boundaries of the classrooms. This case needs to implement practically the studentcentered approach to provide contextualized language learning (Al-shehri, 2011).

*Master, English Language Centre, Deanship of support studies, Taif University, Kingdom of Saudi Arabi

**English Language Centre, Deanship of support studies, Taif University, Kingdom of Saudi Arabi

Email: mohammadsheef@yahoo.com 
There are many reasons for studying English as a foreign language 'EFL.' Probably, some learners want to study English because they think it provides them with a chance for advancement in their professional lives. That is right; too many workers' job evaluation depends on the excellence of their work and their English language proficiency (Ahmed, 2015). Another possible reason for studying English is that many language learners want to keep abreast with the latest technological developments. As well, many young people from all over the world spend a lot of their free time using Internet games.

One important reason for learning and studying English is that it allows multinational students free access to information and research database. Since many of the well-known academic journals are published and printed in English, students and academics need potent English reading and writing skills. Furthermore, for a research bulletin or other publications to become renown, they should be published in English (Harmer, 2002).

\section{Definition of Listening and Listening Comprehension}

Listening is one of the "four skills" of language learning. All language- teaching approaches except for grammar-translation method incorporate a listening component (Flowerdew, John, Miller, \& Lindsay, 2005). It enables students to be aware of language and provides them with the creative use of grammar. Listening helps students acquire detailed comprehension. It also assists them approach a foreign language with greater confidence and expectation of success (Asemota, 2007).

Moreover, listening is defined as the ability to identify and understand what the speaker says by understanding his/her accent, pronunciation, grammar, vocabulary and grasping his/her meaning (Rost,1994). Underwood (1989) defined listening as "the activity of paying attention to and trying to get meaning from something we hear" (p.1 ). Mendelsohn asserted that the listening skill is the ability to decipher the speaker's intention that is required of a competent listener (1994). Moreover, Purdy stated that listening is "the active and dynamic process of attending, perceiving, interpreting, remembering, and responding to the expressed (verbal and nonverbal), needs, concerns, and information offered by other human beings" (1997, p1-20. ).

As to listening comprehension, it includes numerous processes involved in understanding and making sense of any spoken language. These include recognizing the speech sounds, understanding the meaning of individual words, and/or understanding the syntax of sentences in which they are presented (Nadig, 2013). Moreover, listening comprehension is an individual understanding of what one has heard. In addition, it is the listener's ability to repeat the text despite the fact that the listener may repeat the sound without real comprehension (Brown \& Yule, 1983; Hamouda, 2013). Likewise, listening comprehension is an interactive process where linguistic and world knowledge interact when a listener makes a mental representation of what he/she hears (Brown, 2001). 


\section{The Importance of Listening Skill}

Listening skill is a term that is used to refer to a complicated process that allows language learners to understand a spoken language. It is the most useable language skill which is usually associated with the other skills. Furthermore, it is an important language skill to acquire a second language (Rost, 1994). Listening skill has a considerable concern for language teaching and learning. It is one of the prior conditions of speaking skill in language learning process. For this reason, listening skill can be considered as a substantial agent in oral production by setting up a confirmed background for communication (Yavuz, \& Celik, 2017).

Several studies have pointed out that listening comprehension plays a significant role in the learning process. Despite its importance, listening skill has been ignored in learning a second language (SL) by both teachers and researchers (Ahmadi, 2016). Ahmadi claims that listening skill plays an important role in language learning because it provides an input for learners and plays a significant part in the development of learners' language knowledge (Rost, 1994).

Listening skill is a complex mental process that requires cognitive psychological processes such as attention, perception, language use, memory, problem solving, creativity, and thinking. EFL learners often face difficulties in listening comprehension. Therefore, if teachers want to improve their learners' listening ability, they should study their problems critically and work on finding effective listening strategies to help their students overcome these difficulties (Hamouda, 2013).

\section{The Relationship between Listening and other Language Skills}

Listening skill is a widely used language skill among other skills (speaking, reading, and writing). It is considered one of the main four skills in language learning. It is also a crucial means of acquiring a second language. According to applied linguists' consensus, listening is a principal channel by which the language learners gain the second language data (Rost, 2001). Linebarger states that the perception of the world around us and the interpretation of experiences occur through listening (Linebarger,2001).

Many studies show that improvement in listening skill affects other language skills positively. For example, Bergman's study (1999) reveals that listening to and reading stories simultaneously help learners to do better in other skills. Similarly, Morris and Leavey's study (2006), focusing on preschoolers' phonological development, illustrates that the instructions of the listening skill improve preschoolers' phonological perception.

Listening acts as an important factor in developing language communication. A systematic statistic shows that of the total time spent on communication, listening takes up 40-50\%; speaking, 25-30\%; reading, 11-16\%; and writing, about 9\% (Gilakjani \& Ahmadi, 2011). Furthermore, listening is fundamental factor for learners throughout all levels of academic progress (Coakley \& Wolvin, 1997). Other studies pointed out that efficient listening was a more important skill than reading as it is a principal component for academic success (Coakley \& Wolvin, 1997). 


\section{Listening in Second Language Acquisition (SLA)}

In second language acquisition, linguistic environment helps the second language learners gain linguistic input in the form of listening opportunities founded in authentic social and academic situations. Second language learners need to understand the language in these situations to acquire the language through native speakers' accommodations. These accommodations (technological devices, pedagogical aids, classroom facilities, etc.) make language comprehension possible through new teaching strategies (Rost, 1994).

In his hypothesis, Krashen (1982) asserted that the 'comprehensible input' was an important requisite for language learning. He claimed that learners could enhance their development in language acquisition whenever they comprehend linguistic items (phonology, syntax, semantics, and lexicography) which are of a level that is slightly above their current knowledge (1982).

\section{The process and the type of listening}

\section{The process of listening}

Although listening is the most frequently used language skill in daily life, it is the most ignored and underestimated one in EFL context (Ulum, 2015). Such an ignorance usually comes from two factors: First, speaking and writing (the productive skills) are highly visible, and are more easily assessed than listening and reading (the receptive skills). Second, many EFL learners aren't willing to improve their listening skills due to the feeling of being frustrated because of the uncomprehending conversations though understanding the process could help them improve their comprehension (Kline, 1996).

The process of listening moves through three steps: receiving, attending, and understanding respectively (Wong, 2015).

Receiving is an easily understood step. However, many people fail to receive the massage of the sender. Sometimes, the problem is either a physiological or psychological one or something else.

In Attending, one has to choose, whether consciously or unconsciously, to attend to some stimuli and reject others. Receiving and attending are prerequisites to the rest of the listening process.

\section{Understanding}

Listening process may end up with understanding, as effective communication depends on understanding and effective communication does not take place until the receiver understands the message (Kline, 1996).

\section{The Types of Listening}

There are different types of listening in various situations. One may listen to get information, improve a relationship, make distinctions between two things, or get involved in a critical evaluation. Therefore, one should study the different types of listening carefully (Kline, 1996). 


\section{Extensive Listening}

It occurs in a situation as teachers encourage their students to choose what they want to listen to, using their own materials for the purpose of pleasure and language improvement. This type of listening often occurs outside the classroom and students do it at their own pace (Harmer, 1998).

Extensive listening materials can be found in different resources such as television, radio, smart devices' applications, CDs, DVDs, etc. All these sources tend to treat spontaneous conversations, short and long stories, dialogues, interviews, news, etc.

\section{Intensive Listening}

Intensive listening entails great efforts to process precise sounds words, phrases, and grammatical and pragmatic units. It is considered an essential part of listening proficiency (Rost, 2002, 138).

EFL teachers usually prefer to use audio tapes as their favorite material in classroom since it gives students the opportunity to listen to a variety of voices with different accents, and different topics with different styles. It also provides the learner with a significant source of language input (Harmer, 1998).

\section{Appreciative Listening}

This type of listening includes listening to music - for pleasure and enjoyment-, to native speakers - since one likes their style or want to imitate their speech-, to one's choices in theater, television, radio, or film, etc.

\section{Critical Listening}

Critical listening is fundamental everywhere; one uses in different contexts including family, community, job, etc. In critical listening, one makes careful judgements about what he/she hears (Stephen, Lucas, 1998).

\section{Discriminative Listening}

Discriminative listener is sensitive to changes in the speaker's rate, volume, force, pitch, and emphasis. (S)he can detect even nuances of difference in meaning. Sensitivity to pauses and other vocal and nonverbal cues allows critical listeners to more accurately judge not only the speaker's message but his/her intentions as well (Kline, 2003).

\section{Comprehensive Listening}

Comprehensive listening tries to make sense of different sounds of a message. In comprehensive listening, the meaning requires two things: first having a lexicon of words, all rules of grammar and syntax, in addition to the visual components of communication (Kline, 2003).

\section{Listening Comprehension Problems: Saudi Context}

Many EFL learners consider listening skill as a difficult language skill to be acquired. In spite of the significant role of the listening skill in learning a second language, many teachers do not 
concentrate enough on its importance in their classes. The findings of many studies prove that the help and support of the teachers can improve the listening comprehension of language learners using adequate materials and modern teaching methods and strategies (Pourhosein \& Banou, 2016).

Listening comprehension is clearly the weakest skill of EFL learners who encounter different kinds of listening problems. It is also the most underestimated skill in EFL context (Ulum, 2015). Therefore, the researcher is proposing some frequent listening problems encountered by EFL Saudi Secondary Stage Students. The following problems are collected from the researcher's background and other researchers in the pedagogical field (Hamouda, 2013).

\section{Problems Related to Limited English Vocabulary}

The great majority of the EFL students find that unfamiliar words, including jargon and idioms interfere with their listening comprehension. According to Underwood (1989), it is noted that the lack of vocabulary is a big obstacle to most students in listening comprehension.

\section{Problems Related to Weak Grammar}

Difficult grammatical structures cause much trouble to students. This conforms to Vogely's study that shows that the difficulty in listening comprehension is partly due to the structural component of the text (1998).

\section{Problems Related to the Length of a Spoken Text}

The length of the audible text is a major reason that causes students' listening difficulty. Therefore, an appropriate length of listening text needs to be considered for the desired results (Shahid, 2017).

\section{Problems related to unfamiliar topics/subjects}

Familiarity with the topic increases listening comprehension. According to Nuttall, students construct their understanding of the subject they listen based on their experiences; problems arise, therefore, when there is a mismatch between the subject and the previous experience of the learner (1996).

Problems Related to Students' Attempt to Understand Every Single Word in the Text This supports the claims of the study carried out by Butt et al (2010). They think that some foreign language learners try to understand every single word of incoming speech, but actually, doing so is both unnecessary and impossible.

\section{Needed Listening Comprehension Skills}

Gilakjani states that listeners should be able to interpret meaning, apply different strategies, and use interactive processes in deciphering the message (2011). According to Willis (1981), good listeners should possess the necessary skills for listening comprehension. These skills are classified as: (1) predicting topics that learners want to talk about, (2) guessing unknown words or phrases, (3) using previous knowledge and skills to understand the themes, (4) recognizing the 
relevant points and rejecting irrelevant information, (5) using a note-taking technique, (6) recognizing discourse markers such as: well; oh; umm; another thing is; now, initially, etc., (7) recognizing cohesive devices (e.g., such as, which, linking words, pronouns, references, etc.), (8) understanding different intonation patterns and uses of stress which give clues to meaning and social setting, and (9) understanding inferred information, e.g. speakers' attitude or intentions (p. 134).

\section{The Significance of the Study}

The current study highlights using audio-podcasts as a learning tool to improve and develop EFL Saudi Secondary Stage students in listening comprehension skill. The findings may have a great value in enhancing English language ability among Saudi students. Moreover, the findings of the study may change EFL teachers' attitude towards audio-podcasts in teaching listening skill either inside or outside their classrooms. It could also help researchers in their research conduction on EFL listening comprehension.

\section{A Theory Related to the Study: Input Hypothesis}

Stephen Krashen submitted the Monitor Model, a theory of second language acquisition. This theory had five hypotheses that explained the acquisition of a second language. Input Hypothesis is one of these hypotheses (Krashen, 1982).

According to the Input Hypothesis, language learners need comprehensible input to move from their current level of acquisition, to the next level of acquisition. The growth of the learners' knowledge happened when they understand that language input is a bit more above their current understanding of the language. This hypothesis asserts that second language acquisition appears through moderate exposure (not too difficult, not too easy) to comprehensible input. It also entails the innate language acquisition device that allows for the exposure to comprehensible input to result in language acquisition (Zafar, 2009).

\section{Context of the Problem}

According to the researcher's background in teaching for more than fifteen years, Saudi EFL students have serious problems in English listening comprehension. This is because most schools in various stages (whether elementary, intermediate or secondary) often focus on reading, vocabulary and grammar. Listening and speaking skills are not important components of many curricula; but teachers do not seem to pay enough attention to these skills while preparing their lessons. Many teachers take it for granted and believe that they will be developed automatically wihin the process of language learning. Furthermore, listening skill is often difficult and inaccessible for second and foreign language learners due to its implicit nature.

\section{The Statement of the Problem}

A little number of studies indicates uncertainty of the impact of audio-podcasts as an English learning tool for improving and enhancing secondary stage students' listening comprehension (Al Qasim \& Al Fadda, 2013). Furthermore, in spite of the many studies that have described the use 
of podcasts in language learning, they have been undertaken internationally; thus, the number of studies in the Saudi context is still insufficient; especially in the secondary school stage.

The researcher notices that a school education (pre-college stage) is neglected in care and adequate studies, although pre- college stage plays a crucial part in a successful high education academic achievement in the future. Weak students in English proficiency may not complete or may find unaffordable difficulties in their high education. Another reason that attracts the attention of the researcher is that all pioneering public or private universities or institutional settings stipulate high proficiency of the English language. The current study attempts to cover a fundamental skill in learning English language through using a podcast.

\section{The Research Questions}

The researcher poses two questions to account for the goal of the study; they are as follows:

RQ1- Do audio-podcasts affect listening comprehension of Saudi EFL Secondary Stage students?

RQ2- What are the Saudi EFL Secondary Stage students' attitudes towards using the audiopodcasts in classrooms, concerning listening comprehension?

\section{LITERATURE REVIEW}

2.1 The use of technology in education

2.2 Mobile Assisted Language Learning

2.3 The podcast definition

$2.4 \quad$ The origin of podcasts

2.5. The types of podcasts

2.5.1 Audio podcasts

2.5.2 Video podcast

2.5.3 Enhanced podcast

2.5.4 A Screencast

2.6. The significance of podcasts

2.7 podcasts in education

$2.8 \quad$ Considerations for using podcasting

2.9 The application is called "English Listening Practice"

\section{Literature Review}

\subsection{The use of technology in education}

According to Richey, Silber, and Ely (2008), educational technology refers to the study and the appropriate practice of easing and simplifying learning, and improving learners' performance 
through creating, using and managing appropriate technological processes and resources such as computers; projectors; data shows; smart boards; etc. While the Association for Educational Communications and Technology has defined educational technology as "a complex, integrated process involving people, procedures, ideas, devices and organization for analyzing problems and devising, implementing, evaluating and managing solutions to those problems involved in all aspects of human learning" (Association for Educational Communications and Technology, 1977).

Educational technology helps in transferring learning materials to EFL students. This has to be in an easy way and accessible to students as well. Teaching process requires the use of many tools and techniques for successful performance. It helps in raising the effectiveness of learning and teaching processes. All the material resources that help teachers and students be successful in the educational process can be assigned as teaching tools. These tools are an instructive working tool, which promote effective performance at educational settings. On the other hand, one should engage more senses in the implementation of the educational process to have more efficient learning (Trnavac, \& Djordjevic, 1995, p. 320).

Computer is one of the technological devices that makes a radical change in the pedagogical field. At present, computers have played a significant role in the development of the students' proficiency in learning the second/foreign language and fulfilling their needs (Murati, 2013).

The influence of information and communication technology (ICT) increases in many social realms, including the pedagogical domain. The need for the application of ICT in education stems from the fact that not only there is a dire need to prepare young people to become successful in society but also the hopeful future can only be conducted by the ICT. Using computer and information technology in classrooms affects the way that teachers show the various files. It also affects students to view those files in a clearer and more interesting way. In general, computers effectively work to expand and build up knowledge and skills (Murati, 2013).

Computer-Assisted Language Learning (CALL) is briefly defined in a influential work by Levy as "the search for and study of applications of the computer in language teaching and learning" (1997, p. 1). CALL includes a wide range of information and communication technology applications and approaches to teaching and learning foreign languages, ranging from the "traditional" drill-and-practice programs that characterized CALL in the 1960s and 1970s to the more recent manifestations of CALL, (e.g. as used in a virtual learning environment and Webbased distance learning). It also extends to the use of interactive whiteboards (Schmid, 2009); computer-mediated communication (CMC) (Lamy \& Hampel, 2007); and language learning in virtual worlds and mobile-assisted language learning (MALL) (Shield \& Kukulska, 2008). MALL includes devices such as smart cell (mobile) phones, MP3 or MP4 players (e.g. iPods), personal Digital Assistants (PDAs) (e.g. Palm Pilot), laptops, and various electronic tablets (Shield \& Kukulska, 2008). 


\subsection{Mobile Assisted Language Learning}

In general, mobile assisted language learning (MALL) is considered a natural blossom of computer assisted language learning. By the emerging of the Internet and multimedia in our smart devices, people tend to use smart phones and tablets widely for multipurposed usages in the last few years. In addition to the traditional purpose of the verbal communication, the current multifunctional mobile phones enable users to access to the Internet for scheduling, searching information, playing music, emailing, taking notes, reading e-books, providing directions, shopping and many other functions. Moreover, using mobile devices enables students to become more independent in learning (Johnson et al., 2013; Johnson, Adams, \& Cummins, 2012).

Many researchers discussed the applications of mobile technology for educational purposes (Chinnery, 2006; Godwin-Jones, 2011; Kukulska-Hulme \& Shield, 2007/2008). Kukulska-Hulme and Shield (2007) comprehensively conducted a survey to highlight the speaking and listening skills. They overviewed their work in terms of the types of mobile devices including Personal Digital Assistant (PDA), cell phones, tablet PCs, smartwatch, MP3 players, palmtop, etc. Lately, Godwin-Jones (2011) investigated not only the current trend of mobile applications for language learning but also the adding of context-aware-learning applications using GPS, data storage and synchronizing between "cloud" and mobile device. He also emphasized the obvious development of mobile devices' software in vocabulary learning programs and flashcard's software. Because of the increasing spread of the smartphones that have a wireless Internet connection, their educational applications have become varied and integrated more than before.

Brown (2010) stated that mobile devices aim to boost and extend the achievement of teaching and learning processes as well as to spread learning environment among young and adult students. Another study asserted that the features of the mobile devices in learning such as personality, portability, integration, informality, authenticity, extemporaneousness, availability every time and everywhere, and contextualization enhance the significance of these mobile machines increasingly (Kukulska-Hulme, et al., 2005). Kukulska-Hulme also believed that these small portable technologies play a fundamental role in language learning. This new promising field is getting more and more attention because of its powerful effect on young and adult students equally. This technological invention may lead to positive effects in learning environments because of its extensive use and functions such as having audio recording, live polling, mobility, attending online forums, reach ability, localization, doing video projects, and personalization (Levy, \& Kennedy, 2005).

\subsection{The Podcast Definition}

A podcast is an episodic series of digital audio or video files which a user can download in order to listen to. Podcasting episodes are automatically downloaded via web syndication to the user's own local computer, mobile application, or portable media player (Merriam-Webster Dictionary, 2018). 
Another definition in of the podcasts by Merriam-Webster Dictionary says that a podcast is a program (as of music or talk) made available in digital format for automatic download over the Internet (p. 1828).

According to Cambridge Dictionary, a podcast is a radio programme that is stored in a digital form that you can download from the internet and play on a computer or on an MP3 player (Cambridge Dictionary, 1999). While Collins Dictionary defines podcast as an audio file similar to a radio broadcast, that can be downloaded and listened to on a computer or MP3 player (Collins Dictionary, 1819).

Lafferty \& Walch (2006) stated that podcast is a series of digital audio and video recordings uploaded on the web assisted by Rapid Simple Syndication (RSS) feeds. This RSS feeds allow listeners to download their preferred podcasts using podcast client software such as Zune, Winamp, Rhythmbox, Podwalk, Overcast, MusicBee, NewsFire, Media Go, Feebooks, double Twist and iTunes. Lazzari (2009) asserted that a podcasting is a method for diffusing any digital media file, or series of files, over the Internet for playback on portable media players, such as Apple iTouch, Zune 80 GB Digital, Archos 60430 GB portable, Sony X-series Walkman, personal computers, etc. A podcast was originally audio-only but now it contains texts, images, video, and episodes pinpointing some themes or ideas.

\subsection{The origin of podcasts}

A podcast goes back to the 1980s. With the advent of broadband Internet and portable digital audio playback devices such as the iPod and iAUDIO CW100, podcasting began to catch hold in late 2004 (Hammersley, 2004). Today, there are more than 115,000 English-language podcasts available on the Internet, in addition to tens of websites available for distribution at little or no cost to the producer or listener.

A podcast is a term derived from "broadcast," while the term "pod" is derived from the success of the iPod as audio podcasts which are often listened to on portable media players. The files distributed are in audio format, but may, sometimes, include other file formats such as PDF or EPUB. Videos which are shared following a podcast model are sometimes called video podcasts or podcasts (Sawyer, 2015).

In the early stages, podcasting was an unknown method of spreading audio episodes, but now it has become a popular medium for distributing audio files, whether for personal or shared purposes. Generally, podcasts resemble radio programs, but they are found in audio files that can be played anytime and anywhere according to audiences' utilities.

The first implementation to make this process practical and functional was iPodderX when audio podcasts performed what was accomplished through radio broadcasts, which had been the origin of radio news. A remarkable change occurred with the emerging of the Internet potentiality along with the increased numbers of users accessing hardware and software for audio recordings (Watson, 2005). 


\subsection{The Types of Podcasts}

There are basically four types of podcasts that will be uncovered as follows (Podcast, n.d.):

\subsubsection{Audio Podcasts are the Most Common Type of Podcasts}

It is evident that audio podcasts are audio episodes. This type is often founded in MP3 format and the most amicable with all models of PCs and mobile media devices. Audio podcasts have many positive phases including relatively small file size, depending on the demanded length, as well as they are relatively easy to produce.

\subsubsection{Video Podcast is sometimes abbreviated to Vodcast}

Video podcast is used to deliver an online video content. However, the word 'vodcast' from its outset has described the distribution of digital media files, including video and audio contents. With the spread of the Internet, video podcasts have become very popular online and are presented as short video clips. They are also being used for web television, a quickly growing style of digital entertainment that uses various forms of new media to deliver shows or series.

\subsubsection{Enhanced Podcast}

Enhanced podcast is a Combination of Audio Podcast with Synced Image. It often contains multiple still images that change like a slideshow, and here one can also add live URL links to Websites as well as chapter markers to skip around the podcast. Technically, an enhanced podcast is an audio file in MP4 format, with a layer for embedding the synced images. One benefit of enhanced podcasts is that they present both visual and audio content, but the file size is nearly the same as a typical audio-only podcast, and exponentially smaller than a video podcast!

\subsubsection{A Screencast}

A screencast is a digital recording of computer screen output containing audio narration. It is also called a video screen capture. Recent versions of a screencast support more compact file formats such as Adobe Flash, and MP4 and have more sophisticated editing features allowing changes in sequence, mouse movement, and audio. A screencast, in essence, is a movie of the changes over time that a user sees on his/her monitor ("Screencast," n.d.).

\subsection{The Significance of Podcasts}

Podcasting can make the class-matters more interesting, giving the students the opportunity to incorporate listening and speaking in the learning process. Furthermore, teachers can create a more active and collaborative learning environment in their classes (Abdous, Facer, \&Yen, 2012; Abt \& Berry, 2007). Many studies have figured out its competent and efficient role. This supportive technological tool can significantly contribute to the development of language skills, specially speaking and listening (Son, 2018; Ashton-Hay \& Brookes, 2011).

A podcast is an instrument designed to help language teachers foster their students to implement language skills they have acquired in an active way of communication and not just use them as a 
means for collecting information (Wrigglesworth \& Harvor, 2017; Yoshida, 2013; Ashton-Hay \& Brookes, 2011). For example, the process of creating or using a podcast can boost more skills such as language structure, listening, interviewing, script writing, communicating and speaking (Bin et al., 2017; Scutter et al., 2010).

Several worldwide studies have been carried out to investigate the positive effects of the podcasting on learning process. Some studies focus on the difference between the varied number of video-podcasts used and the students' performance in listening comprehension (Shahid, 2017). Other studies focus on the effectiveness of the podcasting in improving the student learning experience when it is integrated into the curriculum or when it used as supplementary material (Abdous, Camarena, \& Facer, 2009). Another study investigates educational podcasting in three domains: the creation and distribution of discourse/speech archives for review, the delivery of supportive pedagogical materials, and the tasks requiring learners to produce their own podcasts (Deal, 2009).

A podcast is considered a dynamic learning and teaching tool in many phases such as beliefs, culture, values and history of the domains where the target language is spoken. Totally, the findings of many studies indicate that language learners were positive towards using podcasts, and that they were concerned to use them into their language learning processes (Ashraf, Noroozi, \& Salami, 2011; Istanto, 2011; Kan, 2011; Hawke, 2010). Students' opportunity to learn at their own time and pace, and to listen to particular materials that they may miss or may not understand multiple times increases the positive perceptions of using podcasting in their learning.

\subsection{Podcasts in Education}

A podcast is a growing trade in the field of education. It is being used both by teachers and students, alike, which gives it a multidimensional aspect. Podcasting is not limited to teachers' content, but learners can also create their own podcasts (Middleton, 2008).

Durbridge (1984) pointed to the pedagogical advantages of audio over printed media, explaining that the spoken word can affect both cognition (adding clarity and meaning) and motivation (by conveying directly a sense of the person creating those words). Podcasts help in establishing social presence (So \& Brush, 2008; Seitzinger, 2006), which is important in online learning, and they help to improve teacher-student relationships (Salmon et al., 2007).

The podcasting proponents think that a podcast can offer unique educational advantages to EFL learners. One of the earliest studies, Clark and Walsh (2004) conducted a study describing the potential of podcasting in education. They emphasized that listening is an innate phenomenon while reading and writing are not; linguistic psychologists have found that children do not learn how to comprehend the verbal/vocal language, but they are connected with this skill (Chan and Lee, 2005). Likewise, Durbridge (1984) asserted the benefits of the audio podcasting for language learning. He stated that the spoken language can affect learners' cognition and motivation by transferring directly as sense of the individuals creating their language as well as 
adding clarity and meaning to it. Moreover, Lee and Chan maintained that short "bite-sized" audio episodes could not only eliminate leisure time in our daily activities but also coincide with the activities for penetrating and extending learning that mingle and combine with the learners' lifestyles. This procedure helps learners to acquire and learn language regardless of the diverse time or sites (Lee and Chan, 2007).

Additionally, there are many advantages of using podcasting such as the simplicity, the ease of subscription and the use across multiple environments, convenience, saving time, the proliferation of portable media players, etc. Podcasting usually simplifies the process of learning and teaching. It encourages creativity and collaboration in the classrooms as well as teaches effective communication skills. Simply, learners subscribe easily to get new updated clips and automatically download them, on a variety of favorite topics, onto their mobile devices (Lee and Chan, 2007).

Furthermore, students get benefit of podcasting in their actve activities, such as discussions, brainstorming, solving problems, students' projects podcasting-delivery, laboratories, and group work (e.g., Gannod et al., 2008). Podcasting also help teachers produce podcasts that summarize theory/concept for their classmates (e.g., Frydenberg 2006).

\subsection{Considerations for Using Podcasting}

It is necessary to mention some central points that teachers have to take into consideration. These points are important to those keen teachers to get the best advantages of this powerful technology in their classes and to engage students in active learning. Podcasting process in the light of educational domain can be meaningfully observed through three main aspects: content-creation, publishing and subscription. Each of these aspects holds opportunities that could be exploited by teachers in the classrooms (Tan, 2019).

Vygotsky's theories emphasize the essential role of social interaction in the development of cognition, whereas the application of the theory to the content-creation aspect of podcasting could be observed clearly (Vygotskoy, 1978). Podcasting can provide students with collaborative skills that enable them to produce a podcast. When they are engaged in producing it, in fact they learn valuable skill in their future professional life such as managing time, problem solving, communication skills, making decision, self-motivation, leadership and adaptability (Borja, 2005).

The publishing aspect of podcasting works for motivating students to improve their performances before the audio recordings are uploaded onto the Internet. When students show a perception of the importance of their audio recordings, their oral performance will be as accurate as possible during the content creation aspect. Besides, when they have published series of podcasts, the documented episodes create an actual portfolio, that could be used to reflect on their learning as teachers assess them formatively. 
The subscription aspect of podcasting is the most exploited one in teaching and learning. Many podcast users are largely engaged by this aspect of podcasting. Podcasting has an obvious influence on the students' behavior as they download the contents frequently and listen to them during their free time or in-between activities (Thorne \& Payne, 2005). The time-shifting ability of podcasting means that students can download and listen to lectures several times at anytime and anywhere. Doing this help students think carefully about what they have heard and potentially boosts their critical thinking (Thomas, 2006).

\subsection{The Application is Called "English Listening Practice"}

English Listening Practice is one of the most useful applications that helps English foreign learners in their vocabulary and comprehension of English language listening. Users can download this application onto their smartphones using IOS or Android mobile operating systems. They just access the apple store or the play store and download it easily. The application is free and can be offline, too.

English Listening Practice application has two authentic lesson types: The first type is the View Lessons, which include interviews with various speakers talking about a wide range of topics (a collection of more than 1100 ESL/EFL listening lessons). The second type is the Mixer Lessons that include listening to six different people sharing their answers for the same question or topic (a collection of more than 150 ESL/EFL listening lessons). Moreover, in case the users encounter any problem, they could contact the application developer through this email (takeyourway.aoc@gmail.com). The application's version is 1.4 .0 and offered by Google Commerce Ltd.

By using this application, learners will improve their accent, and listening and speaking skills in a simple and easy-to-use environment. The popularity of podcasts continues to increase all over the world, especially among EFL/ESL learners. They can learn English every day by listening to podcasts. There are various exercises to help them practice and improve their level of English.

Features of the English Listening Practice Application:

- Over 1500 authentic lessons.

- Available online and free.

- Learners may use it offline.

- Audios of the highest quality.

- Brain training for all ages.

- Provide learners with authentic contexts.

- Vocabulary and comprehension quiz to improve skills.

- Improve accent or learn more words with the correct structure. 
English Listening Practice does not only improve one's English speaking but also one's social life and make the job interesting.

Key words: audio-podcast, mobile learning, smartphones, episodes.

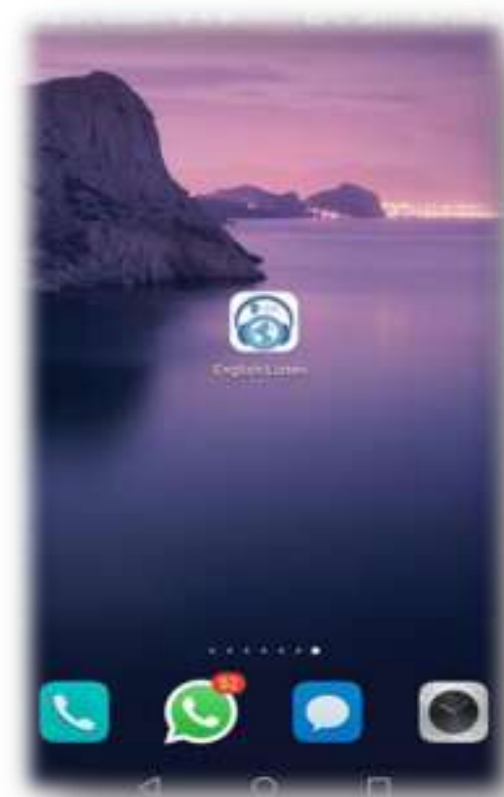

Figure 1: the first phase

\section{package}

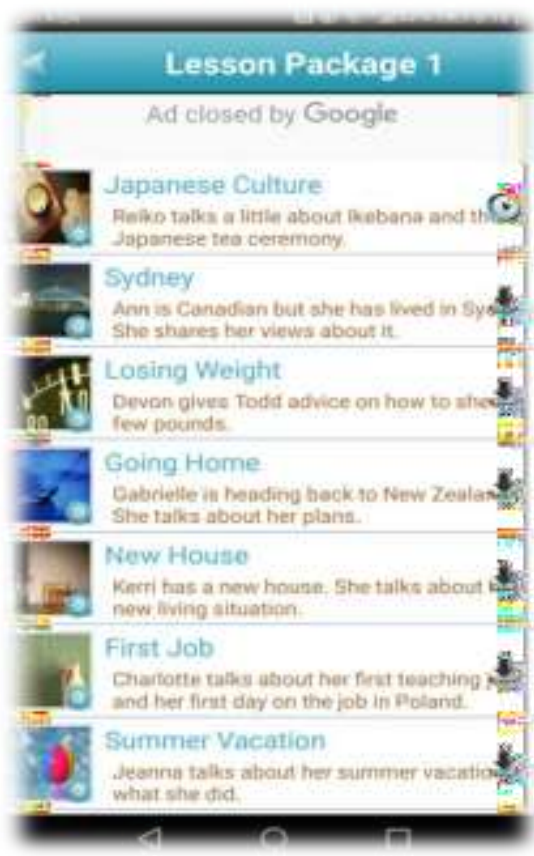

Figure 4: a list of topics
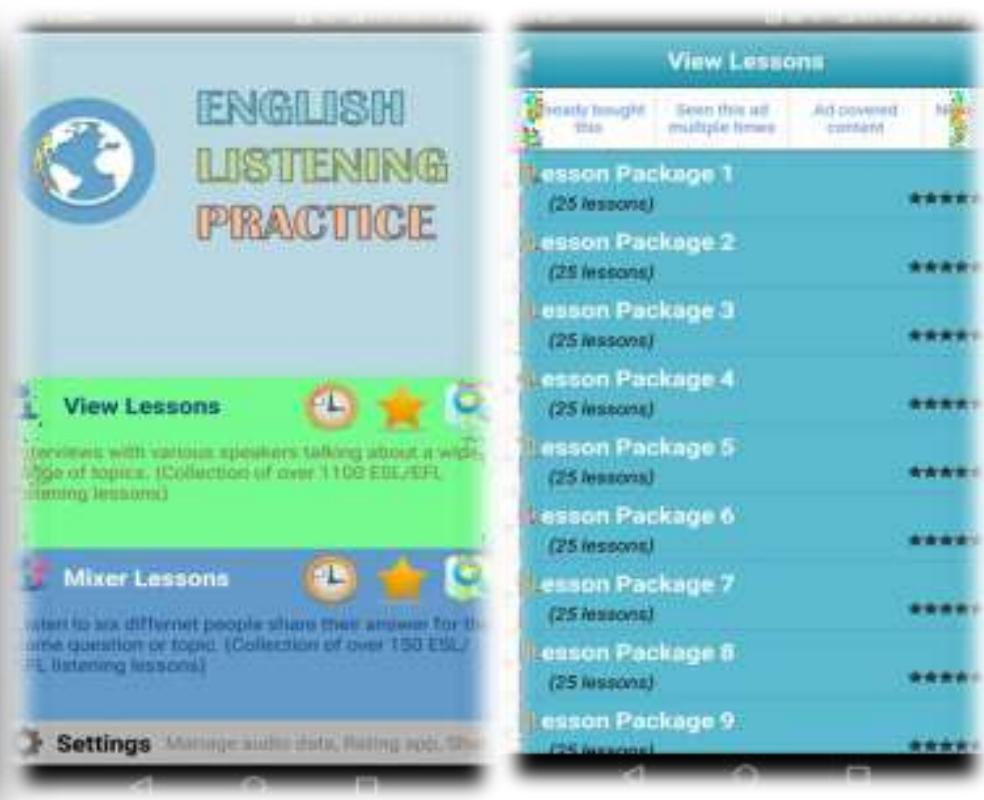

Figure 2: the application interface

Figure 3: the lessons

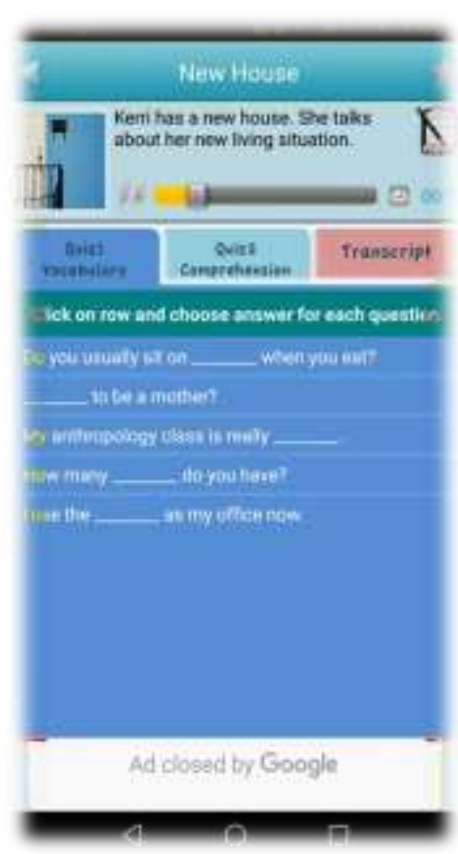

Figure 5: the episode

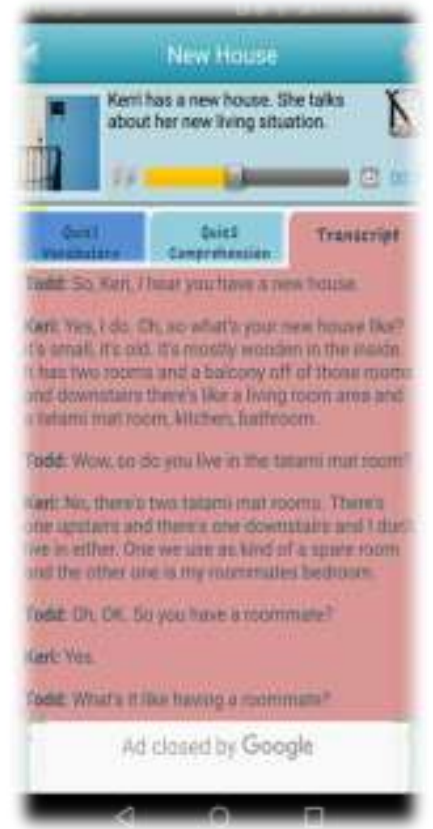

figure 6: the transcript 


\section{METHODOLOGY}

\subsection{Research Design}

3.2 The subjects of the study

3.3 Backgrounds

3.4 Procedure

3.5 Instrumentation

\subsubsection{Pre and Post-tests}

3.5.2 Questionnaire

\subsection{Data Analysis}

\section{Methodology}

\subsection{Research Design}

This study applies the quantitative method with a quasi-experimental pre-test and post-test design to examine the effects of audio-podcasts as a supplementary material in listening comprehension on the third grade of the Saudi EFL Secondary Stage Students.

Robbins states that qualitative research technique is more appropriate for investigating cultural and social phenomenon while quantitative research method is appropriate for investigating research questions and answers (Robbins, 2006). Besides, a quasi-experimental technique is more suitable than the true-experimental technique if random selection is difficult (Creswell, 2002; Taylor, 2008; Wyre, 2007). Additionally, quasi-experimental technique is a proper one to explore the influence of a particular teaching method on foreign language learning. Therefore, a quasiexperimental approach is considered and ideal for investigating influence of audio-podcasts on the third grade of Saudi EFL Secondary Stage Students (Creswell, 2002). Creswell believes that in a quasi-experimental research, the number of sampling is fifteen participants including the control group and experimental group of an experimental study is adequate.

\subsection{The Sample of the Study}

To answer the study questions in the experimental part, the researcher selects participants consisting of 30 male students from the third secondary school grade, located in one of the main cities in the Eastern Province of Saudi Arabia (Qatif). The participants' ages are approximately 18 years old and they have studied English for at least eight years before attaining the third stage of the secondary school. The researcher takes the consent of the study form the school administration and from the students themselves. He has given them sufficient details about the study. 


\subsection{Background}

Both groups, the experimental and the control group, have about three hours and forty-five minutes weekly (each class lasts for forty-five minutes) in learning English language, including the four skills: reading, listening, speaking and writing as well as vocabulary and grammar. Usually, all listening classes are taken place in well-equipped high-tech lab (equipped with a smart board, a projector, a stereo system, a desktop computer, black board, etc.). Because of the cultural nature and the international convergence of petroleum companies, the Eastern Region students always reveal high result in English proficiency according to the National Center for Assessment (Qyas). Supposing, none of the 30 male participants has had experience audio podcasts before implementing the study.

Regarding to the study, the third-grade class of 30 students is divided into group 1(the control group of 15 students) and group 2 (the experimental group of 15 students). Group 1 is taught English listening in traditional way based on teacher-centered technique. While group 2, in addition to the previous way, they are assigned to supplementary 12 audio podcasts in the school lab. A listening comprehension pretest is administered to both groups. The results show no significant difference between the two groups (Appendix 1).

\subsection{Procedure}

The experimental group attends their English classes including listening comprehension, in addition to that they attend the school lab to have audio podcast lessons twice a week. The researcher tells the experimental group to download a "English Listening Practice" application onto their smartphones, because it is a free available application on the Web. None of the participants knows which lesson or which package they will study. The researcher selects the lessons randomly or according to some considerations. The audio-podcast episodes last from 1 to 2 minutes. Participants take two episodes/topics each class twice a week for three weeks. The researcher usually links his smartphone to the smartboard or the projector via a cable or a Bluetooth and gives the participants some instructions (tips, objectives, techniques and listening strategies) before playing the audio-podcasts. Almost, most of the audio podcasts' titles/topics are related in some way to the textbook's titles/topics. After each episode/topic, the researcher provides the participants with appropriate feedback.

Participants have to listen carefully to the audio-podcasts, do exercises (quiz 1: vocabulary, and quiz 2: comprehension), write notes, and read the transcripts after answering the quizzes to enhance their vocabulary. At home, participants could access the application form their own smartphones or any other device, get feedback, and make self-regulation and self-organization. This process lasts for 3 weeks before a post-test is administered to group 2. This procedure starts from 24 February 2019 to 14 March 2019, each session lasts about 45 minutes twice a week. The researcher writes his observations and notes through the learning and training process. 


\subsection{Instrumentation}

\subsubsection{Pre and Post-tests}

A listening comprehension test is carried out to collect data for answering the first enquiry of the study. According to Taylor, a quasi-experimental technique allows researchers to use a pre-test and a post-test to probe into the learning outputs and to test theories by examining the change in post- test scores (2008).

A listening comprehension pretest (Beginner A1 listening: Appendix 1) is applied to measure the two groups' performance before starting the treatment. The pretest contains 11 questions of two types; each type measures a specific listening skill (listening for gist- listening for specific information- listening in detail- listening for attitude and exercises). The first part of the questions includes 6 multiple-choice questions focusing on vocabulary, while the second part includes 5 multiple-choice questions focusing on listening comprehension. However, the outcomes of the two groups show no significant difference (table 1).

Three weeks later, the researcher designs a listening comprehension post-test (Beginner A2 listening: Appendix 2) for both groups to measure the change in the participants' scores in the pre- test and the post-test. The post-test contains 11 questions of two types; each type measures a specific listening skill. The first part of the questions includes 6 multiple-choice questions focusing on vocabulary, while the second part includes 5 multiple-choice questions focusing on listening comprehension.

\subsubsection{Questionnaire}

A 10-item questionnaire is used to explore students' attitude toward the use of audio-podcast by using the 4-point Likert scale (namely, 1 Strongly Disagree, 2 Disagree, 3 Agree and 4 Sstrongly Agree). A psychometric scale is used in studies that employ questionnaires (Carifio, Perla, Rocco, 2007).

Three weeks after the treatment, the researcher designs a 4-point Likert scaled questionnaire and hands it out to each participant in the experimental group. Fifteen students submitted the questionnaire that was taken for data analysis. The data was analyzed by using descriptive statistics of mean and standard deviation with aid of Statistical Package for the Social Sciences (SPSS) version 21.0.

\subsection{Data Analysis}

Statistical Package of the Social Sciences (SPSS) version 21.0 package is used to analyze the data acquired from the study instruments. Students' demographic information is characterized through descriptive statistics. Descriptive statistics is a valuable way that helps researchers sum up and display studies data. An ANOVA method is applied to distinguish between audio-podcasts and pre /post-test listening comprehension test scores (see tables $1 \& 2$ ). ANOVA technique is used to reveal group differences in listening pre-test scores (Trochim, 2006). 


\section{RESULTS AND DISCUSSION}

4.1 The Pre-test first question results

4.2 The pre-test second question results

\subsection{Discussion}

\subsection{Limitation of the study}

\subsection{Conclusion}

\subsection{Recommendation}

4.7 Suggestions for future research

Table 1: The pre-test results

\begin{tabular}{|c|c|c|c|c|c|c|c|}
\hline \multicolumn{4}{|c|}{ The Control Group } & \multicolumn{4}{|c|}{ The Experimental Group } \\
\hline & The result & & & & The result & & \\
\hline No. & $\mid \begin{array}{ll}\text { Out } & o \\
11\end{array}$ & Comprehension & Vocabulary & No. & $\begin{array}{c}\text { Out of } \\
11\end{array}$ & Comprehensior & vocabulary \\
\hline 1 & 6 & 2 & 4 & 1 & 6 & 2 & 4 \\
\hline 2 & 4 & 2 & 2 & 2 & 5 & 1 & 4 \\
\hline 3 & 8 & 3 & 5 & 3 & 8 & 5 & 4 \\
\hline 4 & 4 & 1 & 3 & 4 & 4 & 2 & 2 \\
\hline 5 & 6 & 2 & 4 & 5 & 3 & 0 & 3 \\
\hline 6 & 7 & 4 & 3 & 6 & 6 & 3 & 3 \\
\hline 7 & 9 & 4 & 5 & 7 & 7 & 4 & 3 \\
\hline 8 & 5 & 2 & 3 & 8 & 8 & 3 & 5 \\
\hline 9 & 5 & 1 & 4 & 9 & 5 & 2 & 3 \\
\hline 10 & 7 & 3 & 4 & 10 & 6 & 2 & 4 \\
\hline 11 & 6 & 2 & 4 & 11 & 4 & 1 & 3 \\
\hline 12 & 5 & 3 & 2 & 12 & 6 & 2 & 4 \\
\hline 13 & 6 & 2 & 4 & 13 & 8 & 3 & 5 \\
\hline 14 & 3 & 0 & 3 & 14 & 6 & 2 & 4 \\
\hline 15 & 4 & 1 & 3 & 15 & 6 & 1 & 5 \\
\hline Mean & 5.66 & & & Mean & 5.86 & & \\
\hline Std. & 1.63 & & & Std. & 1.5 & & \\
\hline
\end{tabular}

It is obvious from collected data that there is a very little change between the two groups. No matter, whether the scale is for one favor. 
Table 2: The post-test results

\begin{tabular}{|c|c|c|c|c|c|c|c|}
\hline \multicolumn{3}{|c|}{ The Experimental Group } & \multicolumn{4}{c|}{ The Control Group } & \\
\hline No. & $\begin{array}{c}\text { The result: } \\
\text { Out of } 11\end{array}$ & Comprehension & Vocabulary & No. & $\begin{array}{c}\text { The } \\
\text { result: } \\
\text { Out of } 11\end{array}$ & Comprehension & Vocabulary \\
\hline 1 & 8 & 3 & 5 & 1 & 6 & 3 & 3 \\
\hline 2 & 10 & 6 & 4 & 2 & 5 & 3 & 2 \\
\hline 3 & 8 & 5 & 3 & 3 & 7 & 2 & 5 \\
\hline 4 & 9 & 4 & 5 & 4 & 6 & 4 & 2 \\
\hline 5 & 8 & 4 & 4 & 5 & 6 & 3 & 3 \\
\hline 6 & 10 & 5 & 5 & 6 & 7 & 4 & 3 \\
\hline 7 & 9 & 4 & 5 & 7 & 9 & 5 & 4 \\
\hline 8 & 9 & 4 & 5 & 8 & 5 & 2 & 3 \\
\hline 9 & 10 & 5 & 5 & 9 & 7 & 3 & 4 \\
\hline 10 & 7 & 4 & 3 & 10 & 7 & 3 & 4 \\
\hline 11 & 11 & 6 & 5 & 11 & 6 & 2 & 3 \\
\hline 12 & 10 & 5 & 5 & 12 & 6 & 3 & 4 \\
\hline 13 & 9 & 5 & 4 & 13 & 6 & 2 & 3 \\
\hline 14 & 8 & 5 & 4 & 14 & 5 & 2 & 2 \\
\hline 15 & 11 & 6 & 5 & 15 & 4 & 2 & \\
\hline Mean & 9.13 & & & Mean & 6.13 & & \\
\hline Std. & 1.19 & & & Std. & 1.18 & & \\
\hline
\end{tabular}

Table 3: Mean scores on the students' attitudes on the use of the audio-podcast

\begin{tabular}{|c|c|c|c|c|c|c|c|c|}
\hline $\mathrm{S} / \mathrm{N}$ & Statement & $\mathrm{N}$ & SA & $\mathrm{A}$ & $\mathrm{D}$ & SD & Mean & Decision \\
\hline 1 & $\begin{array}{l}\text { I am mindful of the educational purpose } \\
\text { of the audio podcasts }\end{array}$ & 15 & 11 & 3 & 1 & 0 & 3.6 & Agree \\
\hline 2 & $\begin{array}{l}\text { I find audio podcasts useful for English } \\
\text { language learning }\end{array}$ & 15 & 12 & 3 & 0 & 0 & 3.8 & Agree \\
\hline 3 & I find audio podcasts interesting & 15 & 13 & 1 & 1 & 0 & 3.8 & Agree \\
\hline 4 & $\begin{array}{l}\text { Listening to the podcasts helps illuminate } \\
\text { my } \begin{array}{l}\text { understanding to the } \\
\text { language structure }\end{array}\end{array}$ & 15 & 11 & 2 & 1 & 1 & 3.5 & Agree \\
\hline 5 & $\begin{array}{l}\text { Listening to the podcasts helps me build } \\
\text { up my lexicon }\end{array}$ & 15 & 13 & 2 & 0 & 0 & 3.9 & Agree \\
\hline 6 & $\begin{array}{l}\text { Listening to the audio podcasts after the } \\
\text { class provides me with a productive } \\
\text { feedback }\end{array}$ & 15 & 14 & 1 & 0 & 0 & 3.9 & Agree \\
\hline
\end{tabular}




\begin{tabular}{|c|c|c|c|c|c|c|c|c|}
\hline 7 & $\begin{array}{l}\text { I find the audio podcast useful because it } \\
\text { makes me listen the episodes repeatedly }\end{array}$ & 15 & 12 & 2 & 1 & 0 & 3.7 & Agree \\
\hline 8 & $\begin{array}{l}\text { I feel that using podcasts are not effective } \\
\text { on developing my awareness } \\
\text { of the language learning }\end{array}$ & 15 & 1 & 2 & 5 & 7 & 1.8 & Disagree \\
\hline 9 & $\begin{array}{l}\text { I will not be pleased if audio podcasts are } \\
\text { supplementary in my classes }\end{array}$ & 15 & 0 & 2 & 4 & 9 & 1.5 & Disagree \\
\hline 10 & $\begin{array}{l}\text { Listening to the audio podcasts makes me } \\
\text { more attentive in the class }\end{array}$ & 15 & 10 & 2 & 3 & 0 & 3.4 & Agree \\
\hline \multicolumn{3}{|c|}{ Grand Mean } & & & & & 3.29 & Agree \\
\hline
\end{tabular}

\section{Note: SA: Strongly Agree, A: Agree, D: Disagree, SD: Strongly Disagree, N: The number of the experimental group}

Table 3 reveals the responses of students on their attitude towards the use of audio- podcasts. The table also demonstrates that the mean score for each of the ten items on the questionnaire is above (2.5) (the average), while the grand mean score of the ten items is (3.29). This shows that students have positive attitude towards the use of audio-podcasts in listening comprehension when they learn English as a second language. The score of the average mean (2.5) is calculated when one adds each value of the 4-point Likert scale and divide them by $4(\mathrm{SA}=4, \mathrm{~A}=3, \mathrm{D}=2$, $\mathrm{SD}=1,4+3+2+1=10$ divided by $4=2.5$ ).

\subsection{The Pre-test first question results}

The pre-test was given before the beginning of experiment while the post-test is managed after three weeks of the experiment to measure students' performance before and after it. Scores of the students were analyzed to answer the first research question.

RQ1: Do audio-podcasts affect listening comprehension of Saudi EFL third-grade secondary stage students?

Concerning to data analysis, ANOVA technique was used to find out the difference between the pre/post-test scores of the participants. Tables 1 and 2 explain the results of the ANOVA analysis of the pre-test scores. Table 1 includes the mean and standard deviation of listening comprehension pre-test scores of the control and experimental groups. The control group scored a mean of (5.66), while the experimental group scored a mean of (5.86). Table 1 describes the results of ANOVA analysis for the pre-test of the control group and experimental group in the pretest. These results reveal that no significant difference is found between the two groups. It means that the participants of the two groups are of the same level of listening comprehension before the treatment. While table 2 includes the mean and standard deviation of listening comprehension post-test scores of the both groups. The results show that the experimental group did much better than the control group on the post-test. 


\subsection{The pre-test second question results}

The results of the second pre-test question:

RQ2: What are the EFL third-grade secondary stage students' attitudes towards using the audiopodcasts in EFL classrooms, concerning listening comprehension?

In answering the research second question, the researcher collects data on students' attitude towards the use of audio-podcast. A total number of 15 students implement the podcast and complete the questionnaires. They respond to the questionnaire ten items, and their responses were analyzed using the mean scores. The results are shown in table 3 below.

\subsection{Discussion}

The post-test students' scores show that the use of audio-podcasts has considerable positive influence on the experimental group. The experimental group, who are taught and trained with supplementary audio-podcasts, makes considerable improvement in the post-test scores as compared to those in the control group using traditional method in learning listening comprehension without any audio-podcasts.

This result could be related to brain's functions. Wang states that Broca's and Wernicke's areas are related to human listening in a way or another. Wernicke's area is crucial for language development. It is responsible for the acquisition and understanding of listening, whereas Broca's area is connected to the language production. Both functions help human acquire and understand listening input. Moreover, learning is a multi-sensory (1986). This means that students learn better if they taught using more than one sense. So, the combination of audio and written (reading and analyzing transcripts) stimulation provides extra brain interactions and better improvement in learning than the listening alone (Kuo, 2009).

Additionally, one could ascribe the study results to the Input Hypothesis, which assumes that people acquire language by either understanding speech or receiving comprehensible input (Krashen, 1988). In agreement with the Input Hypothesis, second language individuals require comprehensible input to move from the present level of acquired language to the next level. Comprehensible input has to include a structure that is "a little beyond" the present perception, focusing on the meaning of the input rather than the form. Therefore, second language acquisition occurs through enough exposure to comprehensible language. In short, as if one spoon-feeds the second language learners' mind (language acquisition device: LAD) with more extra input through intermittent podcasts' sessions in the class (Chomsky, 1965).

The result of the current study is partially concord with the study by Nada Al Qasim and Hind Al Fadda (2013). Their study revealed that podcasts have positive effects on Saudi participants' listening comprehension. The study also helps practitioners in higher education to use podcasts (pedagogical design's podcasts). There is no doubt that podcasts are a valuable tool for ESL/EFL students, since in the modern environment, a mobile education tool increases the chance of students' engagement in learning process, especially when they consider the authenticity of their 
effort and autonomy. It is obvious that podcasts positively connect learners with each other better than traditional media.

The results of the current study also accord partially with the study by Somayeh Naseri and Khalil Motallebzadeh (2016). The study examined the influence of listening to podcasts on Iranian upper-intermediate EFL students' self-regulation ability and their perception of the technology usage. The result of that study approved that listening to podcasts significantly affected Iranian upper-intermediate EFL students' self-regulation ability. Moreover, many scientific studies were conducted to explore the effect of podcasts on listening comprehension of EFL/ESL learners. Most of those studies concluded that listening to podcasts could boost and enhance and improve the language and oral skills, vocabulary learning, grammar, and language structure. Studies like the ones done by Vandergrift (2006); Kan (2010); Ashraf, Noroozi, and Salami (2011); Hasan and Hoon (2013); Kargozari and Zarinkamar (2014) focused on language oral skills and language proficiency.

Concerning the second question of the study, the results of the mean scores show that the students have favorable attitude towards using audio-podcasts for learning English as a second language. These results are in line with the studies by Brookes (2010) who announced that students' attitudes towards the use of podcasts were positive. The current study also agrees with the findings of Carvalho et al. (2008) who stated that students' attitudes towards the use of podcasts showed a favorable manner. It also accords with the findings of Wilczak (2013) who said that students had positive attitude towards the use of podcasts.

\subsection{Limitations of the study}

First, the participants of the study were from one region of the Kingdom of Saudi Arabia, since that region differs in many aspects from other regions. Therefore, we can't generalize the result of the study.

Second, the treatment of the study has quite short time (three-weeks) that may affect the results. The researcher believes that the treatment should be extended more (from 8 to 12 weeks).

\subsection{Conclusion}

The third-grade Saudi EFL Secondary Stage students have implemented many classes using audio- podcasts via the teacher's smart phone and their own mobile phones. It is clear that the result of using audio-podcasts as a powerful technological tool and a useful supplementary means of teaching and learning English as a foreign language has a great positive effectiveness on Saudi EFL Secondary Stage students. This technology proves its efficacy on Saudi Secondary Stage students in English language proficiency in general, and listening comprehension, in particular. Furthermore, the findings of the study have proved that Saudi students have positive attitude towards using the audio-podcasts. Moreover, in the present study, EFL teachers and students feel more stimulated and active as they use this wonderful technology. It is noteworthy to mention that the role of the teacher plays a crucial part in achieving desired results. Teacher has to focus 
on pedagogical design of the audio-podcasts and consider the educational level of his students to maximize the effectiveness.

\subsection{Recommendations}

According the findings of the current study, the researcher recommends that: stakeholders should incorporate this valuable learning application into Saudi EFL Secondary Stage students' curricula as a supplementary tool.

The study supports the notion that the use of audio- podcasts can make a positive and significant difference to listening comprehension, so it is recommended that this tool be used as a complementary learning aid, particularly since it pleases most of the students because they can learn at any place and anytime.

\subsection{Suggestions for future research}

- $\quad$ Future researches should examine the impact of using audio- podcasts on students over a longer period of time, perhaps one term or more.

- $\quad$ Future researches should focus on unanswered questions in the literature.

- $\quad$ Future researches should cover students from different school stages/levels.

\section{References}

Abdous, M., Camarena, M., \& Facer, B. R. (2009). MALL technology: use of academic podcasting in the foreign language classroom. ReCALL, 20(1), pp. 1-20.

Abdous, M., Facer, B. R., \& Yen, C. (2012). Academic effectiveness of podcasting: A comparative study of integrated versus supplemental use of podcasting in second language classes. Computers \& Education, 58, pp. 43-52. https://doi.org/10.1016/j.compedu.2011.08.021

Abt, G., \& Barry, T. (2007). The quantitative effect of students using podcasts in a first year undergraduate exercise physiology module. Bioscience Education, 10(1), pp. 1-9. https://doi.org/10.3108/beej.10.8

Ahmed, S. (2015). Attitudes towards English Language Learning among EFL Learners at UMSKAL. Journal of Education and Practice, 6, pp. 1-12.

Ahmadi, S. M. (2016). "The Importance of Listening Comprehension in Language Learning. International Journal of Research in English Education. November 2016, 1. Al Qasim, N., \& Al Fadda, H. (2013). From call to mall: the effectiveness of podcast on EFL

Higher education students' listening comprehension. English Language Teaching, 6(9), 30.

Al-Shehri, S. (2011). Connectivism: A new pathway for theorising and promoting mobile language learning. International Journal of Innovation and Leadership on the Teaching of Humanities, 1(2), 10-31. 
Asemota, H.E. (2007). Applied Linguistics. Patcell Global Resources. Benin, Nigeria.

Ashraf, H., Noroozi, S., \& Salami, M. (2011). E-listening: The Promotion of EFL Listening Skill via Educational Podcasts. Proceedings of the $6^{\text {th }}$ International Conference on e Learning (ICEL) (pp. 10-17). Oxfordshire, UK: Academic Conferences and Publishing International Limited.

Ashton-Hay, S., \& Brookes, D. (2011). Here's a story: Using student podcasts to raise awareness of language learning strategies. EA Journal, 26(2), 15-27.

Association for Educational Communications and Technology (1977). The definition of educational technology. Washington, D.C.: Association for Educational Communications and Technology.

Bin, Z., Xinxin, Y., \& Hui, L. (2017). Students' Perspectives on Using Online Sources and Apps for EFL Learning in the Mobile-Assisted Language Learning Context. Handbook of Research on Integrating Technology into Contemporary Language Learning and Teaching.

Borja, R. R. (2005). Podcasting craze comes to K-12 schools. Education Week, 25, 14.

Retrieved June 09, 2006, from Academic Search Premier database.

Brookes, M. (2010). An evaluation of the impact of formative feedback podcasts on the student learning experience. Journal of Hospitality, Leisure, Sport and Tourism Education, 9(1), pp. 5364.

Brown, H. D. (2001). Teaching by principles: An interactive approach to language pedagogy, second edition. New York: Longman.

Butt, M. N. et al. (2010). Listening comprehension problems among the students: A case studyof three govt. boys' higher secondary schools. European Journal of Social Sciences. 18(2) pp: 311315 .

Çakır, I. (2016). Mobile-assisted language learning (MALL).

Cain, K., Oakhill, J. V., \& Lemmon, K. (2004). Individual differences in the inference of word meanings from context: The influence of reading comprehension, vocabulary knowledge, and memory capacity. Journal of Educational Psychology, 96,

pp. 671-681.

Carifio, J., Perla, R., J. (2007). "Ten common misunderstandings, misconceptions, persistent myths and urban legends about Likert scales and Likert response formats and their antidotes". Journal of Social Sciences. 3(3), pp. 106-116.

Carvalho, A. A., Cruz, S., \& Moura, A. (2008). Pedagogical potentialities of podcasts in learning - reactions from k-12 to university students in Portugal. In S. Wheeler, D. Brown \& A. Kassam (Eds), Conference Proceedings of LYICT 2008. (pp. 23-32), Kuala Lumpur, Malaysia. Retrieved from http://goo.gl/NAzTaH 
Clark, D., \& Walsh, S. (2004). iPod-learning. [White paper]. Brighton, UK: Epic Group. Creswell, J. W. (2002). Educational research: Planning, conducting, and evaluating quantitative. New Jersey: Upper Saddle River.

Dashtestani, R. (2013). Implementing mobile-assisted language learning (MALL) in an EFL context: Iranian EFL teachers' perspectives on challenges and affordances. The JALT CALL Journal. 9, pp. 149-168.

Deal, A. (2009). "Collaboration Tools." Teaching with technology white paper.

[Def. 1]. (n.d.). Merriam-Webster Online. In Merriam-Webster. Retrieved November 26, 2018, from https://www.merriam-webster. Com/dictionary/Podcast.

[Def. 2]. (n.d.). Cambridge.org Online. In Cambridge Dictionary. Retrieved November 26, 2018, from https://dictionary.cambridge.org/dictionary/english/podcast

[Def. 3]. (n.d.). Collins Dictionary Online. In Collins Dictionary. Retrieved November 26, 2018, from https://www.collinsdictionary.com/dictionary/english/podcast

"Definition of Podcast". Merriam-Webster. Retrieved November 15, 2017.

Durbridge, N. (1984). Audio cassettes. In A. W. Bates (ed.), The Role of technology in distance education (pp. 99-107). Kent, UK: Croom Helm.

Durbridge, N. (1984). Media in course design, No. 9, audio cassettes. The role of technology in distance education. Kent, UK: Croom Helm.

Fernandez, V., Sallan, J., \& Simo, P. (2015). Past, present, and future of podcasting in

Higher Education. 10.1007/978-3-642-

55352-3_14. https://icoblog.wordpress.com/2009/07/07/types-of-podcasts/

Flowerdew, J., \& Miller, L. (2005). Second language listening: Theory and practice. p. 4. ISBN 0521786479 .

Frydenberg, M. (2006). Principles and pedagogy: The two P's of podcasting in the information technology classroom. The Proceedings of ISECON, 23(x3354).

Gannod, G. C., Burge, J. E., \& Helmick, M. T. (2008). Using the inverted classroom to teach software engineering. Proceedings of the 30th International Conference on Software Engineering (pp. 777-786). Leipzig, Germany: ACM.

Gilakjani, A. P. \& Ahmadi, M.R. (2011). A study of factors affecting EFL learners' English listening comprehension and the strategies for improvement. Journal of Language Teaching and Research, 2(5), pp. 977-988.

Coakley, C., \& Wolvin, A. (1997). Listening in the educational environment. In M. Purdy \& D. Borisoff (Eds.), Listening in everyday life: A personal and professional approach (2nd ed.) (pp. 179-212). Lanham, MD: University Press of America. 
Godwin-Jones, R. (2011). Emerging technologies: Mobile apps for language learning. Language Learning \& Technology, 15(2), pp. 2-11.

Goyal, S. (2012). E-learning: Future of education. Journal of Education and Learning (EduLearn). 6. 239. 10.11591/edulearn. v6i4. pp.168.

Hammersley, B. (2004). "Audible revolution." The Guardian. Archived from the original on 2013-09-22.

Hamouda, A. (2013). An investigation of listening comprehension problems encountered bySaudi students in the EL listening classroom. International Journal of Academic Research in Progressive Education and Development, pp. 2226-6348.

Harmer, J. (2002). How to teach English. London: Longman.

Howatt, A. \& J. Dakin. (1974). Language laboratory materials, ed. J. P. B. Allen, S. P. B. Allen, and S. P. Corder.

Higgins, J. (1983). "Computer assisted language learning." Language Teaching. 16(2), pp. 102114.

Istanto, W. I., \& Indrianti. (2011). Pelangi Bahasa Indonesia podcast: What, why and how? Electronic Journal of Foreign Language Teaching, 8(1), pp. 371-384. Retrieved from http://eflt.nus.edu.sg

Johnson, L., Adams, S., \& Cummins, M. (2012). The NMC horizon report: 2012 higher education edition. Retrieved from http://akgul.bilkent.edu.tr/nmc/2012-Horizon-Report-HE.pdf

Joshi, A., Kale, S., Chandel, S. \& Pal, D. (2015). Likert scale: Explored and explained. British Journal of Applied Science \& Technology. 7. pp. 396-403. 10.9734/BJAST/2015/14975.

Kay, R. (2012). Exploring the use of video podcasts in education: A comprehensive review of the literature. Computers in Human Behavior. 28. pp. 820-831. 10.1016/j.chb.2012.01.011.

Kline, J. A. (1996). Listening effectively. Maxwell Air Force Base, Ala., Air University Press. Krashen, S. D. (1982). Principles and practice in second language acquisition. Oxford: Pergamon. Krashen, S. D. (1988). Second language acquisition and second language learning. Prentice- Hall International.

Kukulska-Hulme, A., \& Shield, L. (2007). An overview of mobile assisted language learning: Can mobile devices support collaborative practice in speaking and listening. EuroCALL 2007. Retrieved from http://citeseerx.ist.psu.edu/viewdoc/download?doi=10.1.1.84.1398\&rep=rep1\&type=pdf

Kukulska-Hulme, A., Evans, D., \& Traxler, J. (2005). Landscape study on the use of mobile and wireless.

Kuo, L., L. (2009). The effects of YouTube listening/viewing activities on Taiwanese EFL learners' listening comprehension: ERIC. 
Lafferty, M., \& Walch, R. (2006). Tricks of the podcasting masters. New York: Que.

Lazzari, M. (2009). Creative use of podcasting in higher education and its effect on competitive agency. Computers \& Education, 52(1), 27-34.

Lee, M. J. W., \& Chan, A. (2007b). Pervasive, lifestyle-integrated mobile learning for distance learners: An analysis and unexpected results from a podcasting study. Open Learning. The Journal of Open and Distance Learning, 22(3), pp. 201-218.

Levy, M. (1997). CALL: context and conceptualisation, Oxford: Oxford University Press.

Levy, M., \& C. Kennedy. (2005). Learning Italian via mobile SMS. Handbook for educators and trainers, London: Routledge. pp. 76-83.

Likert, R. (1932). A Technique for the measurement of attitudes. Archives of Psychology, 140, 155.

Masudul Hasan, M. \& Tan, B. H. (2013). Podcast applications in language learning: A review of recent studies. English Language Teaching. 6. 10.5539/elt.v6n2. p. 128.

Middleton, A. (2008). 100 great ideas for educational podcasting. Retrieved Dec 20, 2018, from http://teaching.shu.ac.uk/ podcast/pdf/edpodworkbook.pdf

Mendelsohn, D. J. (1994). Learning to listen: A strategy-based approach for the second language learner. San Diego: Dominie Press.

Muhammad Naeem Butt et al (2010). Listening Comprehension Problems among the Students: A Case Study of Three Govt. Boys' Higher Secondary Schools. European Journal of Social Sciences, 18(2).

Murati, X. (2013). Teknologiia mësimore, Luma grafik, Tetovë Nadig, A. (2013). Listening comprehension. In: Volkmar F.R. (eds) Encyclopedia of autism spectrum disorders. Springer, New York, NY.

Naseri, S., \& Motallebzadeh, K. (2016). Podcasts: A Factor to Improve Iranian EFL Learner' Self- Regulation Ability and Use of Technology. Educational Technology \& Society, 19(2), pp. 328-339.

Noam Chomsky, Aspects of the Theory of Syntax, MIT Press, 1965.

Nuttall, C. (1996). Teaching reading skills in a foreign language. Oxford: Heinemann English Language Teaching. Chapter 8: An extensive reading programme.” pp. 127-148.

Pegrum M. (2009) From blogs to bombs: The future of digital technologies in education, Perth: University of Western Australia Press.

Podcast. (n.d.). In Wikipedia. Retrieved March 14, 2019, from https://en.wikipedia.org/wiki/Podcast 
Pourhosein Gilakjani, Abbas \& Banou Sabouri, Narjes. (2016). The significance of listening comprehension in English language teaching. Theory and Practice in Language Studies. 6. 1670. 10.17507/tpls.0608.22.

Purdy, M. (1997). What is listening? In M. Purdy \& D. Borisoff (Eds.), Listening in everyday life: A personal and professional approach (2nd ed.) (pp. 1-20). Lanham, MD: University Press of America.

Richey, R. C., Silber, K. H., \& Ely, D. P. (2008). Reflections on the 2008 AECT Definitions of the Field. TechTrends, 52(1), pp. 24-25.

Robbins, P. (2006). A quasi-experimental retrospective study of third-grade small group reading interventions. University of Phoenix.

Rost, M. (1994). Introducing listening. London: Penguin books. Rost, M. (2002) Teaching and researching listening $\left(2^{\text {nd }} \mathrm{Ed}\right.$.)

Salaberry, M., R. (2001). The use of technology for second language learning and teaching: A retrospective. The Modern Language Journal, 85(1),

39-56.

Salmon, G., Nie, M., \& Edirisingha, P. (2007). Informal mobile podcasting and learning adaptation (IMPALA). e-Learning. Research Project Report 06/07 (pp. 1-89). Beyond Distance Research Alliance. University of Leicester.

Sawyer, Miranda (November 20, 2015). "The man who accidentally invented the word 'podcast'" (MP3). BBC Radio 4. Retrieved November 15, 2018.

Scutter, S., Stupans, I., Sawyer, T., \& King, S. (2010). How do students use podcasts to support learning? Australasian Journal of Educational Technology, 26(2), $\quad$ pp. 180-191.

Shahid, S., \& Ali, Z. (2017). Effects of video-podcasts on listening comprehension of Saudi EFL learners. $\quad$ European Journal of English Language Teaching, 0. Retrieved

Seitzinger, J. (2006). Be Constructive: Blogs, Podcasts and Wikis as Constructive Learning Tools. The eLearning Guild's - Learning Solutions - Practical Applications of Technology for Learning e-Magazine, July 31, pp. 1-16.

Son, J. B. (2018). Language Skill-Based Approach. In: Teacher Development in TechnologyEnhanced Language Teaching. Palgrave Macmillan, Cham. https://doi.org/10.1007/978-3- 31975711-7_6

Tan, Y., H., \& Kok, T., M. (2019). Audio blogging and podcasting in education. The 4 types of podcasts. (July 7, 2009). Retrieved from https://icoblog.wordpress.com/2009/07/07/types- ofpodcasts/

Thomas, K. (2006). The power of the podcast. Retrieved June 14, 2006 from http://www.futurelab.org.uk/viewpoint/art70.htm 
Thorne, Steven L. \& Payne, J. Scott (2005). Evolutionary trajectories, internet-mediated expression, and language education. CALICO Journal, 22(3), pp. 371-397.

Trochim, W. (2007). The research methods knowledge base.

Trnavac, N \& Gjorgjevic, J. (1995). Pedagogija, Naucna Knjiga, Beograd.

Taylor, M. (2008). Orthographic and phonological awareness among L1 Arabic ESL learners: A quasiexperimental study: ProQuest.

Ulum, Ö. (2015). Listening: The ignored skill in EFL context. International Journal of Humanities Social Sciences and Education.

Underwood, M. (1988). Teaching listening. New York Longman.

Wang, W. S.-Y. (1986). Language, writing, and the computer: readings from Scientific American: Freeman.

Watson, Stephanie (March 26, 2005). "How Podcasting Works \& Podcasting History". HowStuffWorks. Retrieved November 15, 2017.

Wilczak, D. (2013). The effects of blogging and podcasting on student achievement and attitude in the sixth grade science classroom. (Unpublished master's thesis). Department of Science Education, Montana State University, Montana. Retrieved from http://goo.gl/T3Rxk9

Willis, J. (1981). Teaching English through English. London: Longman.

Wong, A. (2015). The Act of Listening: The processes involved in listening comprehension. Hirao School of Management Review. 5. pp. 73-80.

Wrigglesworth, J., \& Harvor, F. (2017). Making their own landscape: smartphones and student designed language learning environments. Computer Assisted Language Learning, 31(4), pp. 437-458. https://doi.org/10.1080/09588221.2017.1412986.

Wyre, S. H. (2007). Critical thinking, metacognition, and epistemological beliefs. University of Phoenix.

Yavuz, F. \& Celik, O. (2017). The importance of listening in communication. Global Journal of Psychology Research: New Trends and Issues. 7(1), pp. 8-11.

Yenkimaleki, M. (2017). Developing listening comprehension skills by interpreter trainees through prosody teaching: does methodology make a difference?. Educational Research Review. 3. pp. 26-42. 10.20319/pijss.2017.32.2642.

Vogely, A. J. (1998). Listening comprehension anxiety: Students' reported sources and solutions.

Foreign Language Annals, 31(1), pp. 67-80. https://doi.org/10.1111/j.1944- 9720.1998.tb01333.x

Vygotskoy, L. S. (1978). Mind in society: The development of higher psychological processes.

Cambridge, MA: Harvard University Press.

Yoshida, R. (2013). Learners' self-concept and use of the target language in foreign language classrooms. System, 41, pp. 935-951. https://doi.org/10.1016/j.system.2013.09.003 
مجلة البحث العلمي في التربية

مدى تأثير الوسائط الصوتية على استيعاب المسموع لاى طلاب المرحلة

الثانوية في المملكة العربية السعودية: المنطقة الشرقية.

أ/ محمد بن مكي بن عبد الله آل شيف.

الماجستير في الآداب، تدريس اللغة الإنجليزية لغير الناطقين بها، مركز اللغة الأنكليزية، كلية الدراسات

المساندة، جامعة الطائف، المملكة العربية السعودية.

البريد الالكتروني:

\section{د/ نايف سعد الثيتي}

مركز اللغة الأنكليزية، كلية الدر اسات المساندة، جامعة الطائف، المملكة العربية السعودية.

الملخص

تهدف الدر اسة للتحقق من مدى تأثثر الوسائط الصوتية، كوسيلة تعلم وتعليم حديثة، على الاستيعاب السمعي

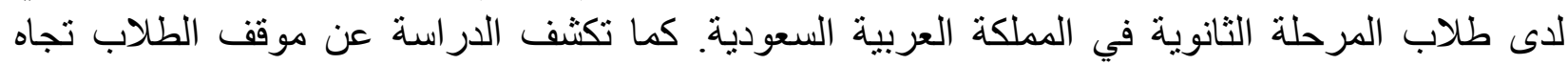

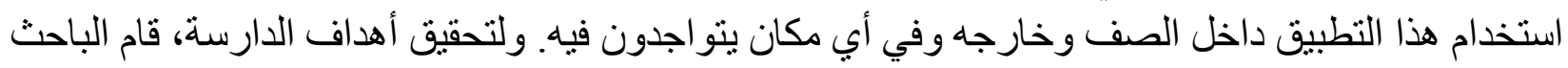

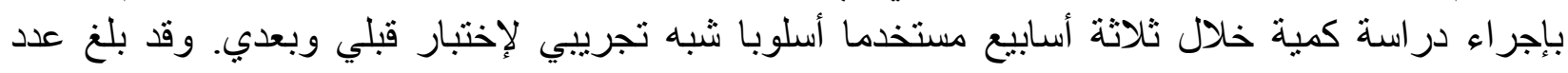

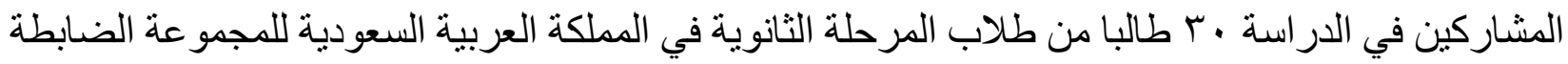

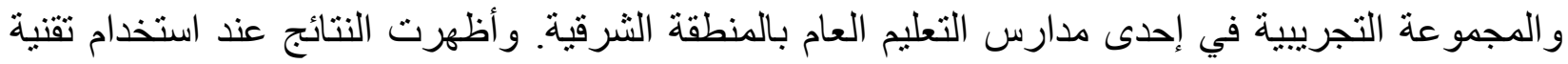

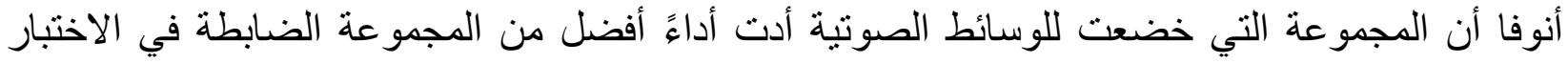

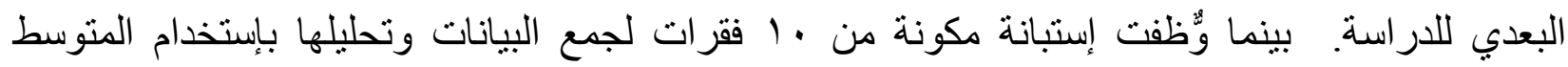

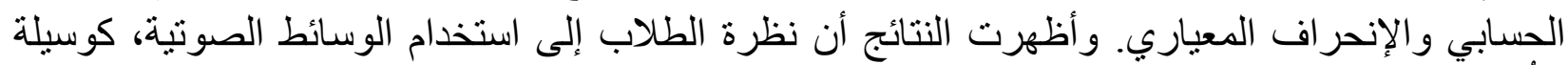

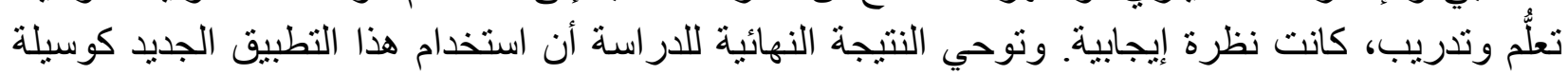

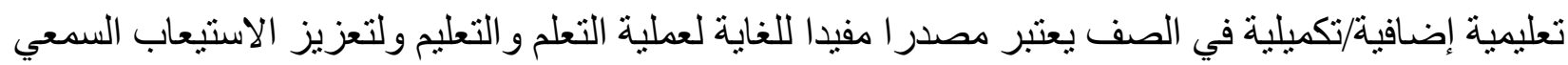
لاى متعلمي اللغة الإنجليزية كلغة أجنبية.

الكلمات المفتاحية: الوسائط الصوتية، الاستيعاب السمعي، الطلاب السعوديون كمتعلمي اللغة الإنجليزية كلغة

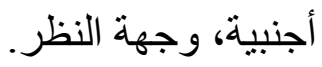

